\title{
Publisher Correction: The International Scientific Association of Probiotics and Prebiotics (ISAPP) consensus statement on the definition and scope of postbiotics
}

\author{
Seppo Salminen (D), Maria Carmen Collado, Akihito Endo (D), Colin Hill (D), Sarah Lebeer, Eamonn M. M. Quigley (D), \\ Mary Ellen Sanders (D), Raanan Shamir, Jonathan R. Swann, Hania Szajewska (D) and Gabriel Vinderola
}

Correction to: Nature Reviews Gastroenterology \& Hepatology https://doi.org/10.1038/s41575-021-00440-6, published online 4 May 2021.

In the original version of this Consensus Statement article published online, a bar in Figure 1 was incorrectly labelled as "parabiotics" when it should have been labelled as "paraprobiotics". This error has now been corrected in the HTML and PDF version of the article.

Figure 1 | Total number of mentions in the literature of different terms referring to inanimate microorganisms and/or their metabolites.

https://doi.org/10.1038/s41575-021-00481-x I Published online 15 June 2021

\begin{abstract}
(1) Open Access This article is licensed under a Creative Commons Attribution 4.0 International License, which permits use, sharing, adaptation, distribution and reproduction in any medium or format, as long as you give appropriate credit to the original author(s) and the source, provide a link to the Creative Commons license, and indicate if changes were made. The images or other third party material in this article are included in the article's Creative Commons license, unless indicated otherwise in a credit line to the were made. The images or other third party material in this article are included in the article's Creative Commons license, unless indicated otherwise in a credit line to the
material. If material is not included in the article's Creative Commons license and your intended use is not permitted by statutory regulation or exceeds the permitted use, you will need to obtain permission directly from the copyright holder. To view a copy of this license, visit http://creativecommons.org/licenses/by/4.0/.
\end{abstract}

(c) The Author(s) 2021, corrected publication 2021

OPEN

\section{Publisher Correction: Publisher Correction: The International Scientific Association of Probiotics and Prebiotics (ISAPP) consensus statement on the definition and scope of postbiotics}

\author{
Seppo Salminen (1), Maria Carmen Collado, Akihito Endo (D), Colin Hill(D), Sarah Lebeer, Eamonn M. M. Quigley(D), \\ Mary Ellen Sanders (D), Raanan Shamir, Jonathan R. Swann, Hania Szajewska (D) and Gabriel Vinderola
}

Correction to: Nature Reviews Gastroenterology \& Hepatology https://doi.org/10.1038/s41575-021-00481-x, published online 15 June 2021.

In the original Publisher Correction relating to Salminen et al., the copyright holder was incorrect and the Publisher Correction should have been Open Access. This issue has now been corrected.

https://doi.org/10.1038/s41575-021-00506-5 I Published online 29 July 2021

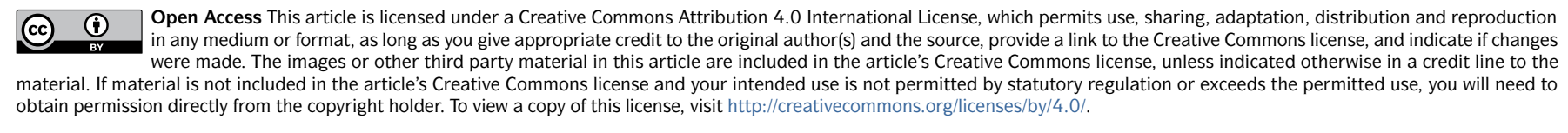

(C) The Author(s) 2021 